\title{
Spatial Heterogeneity, Broadband, and New Firm Formation
}

DOI: 10.12776/QIP.V21I1.791

\author{
Jitendra Parajuli, Kingsley E. Haynes
}

Received: 17 September 2016 Accepted: 25 October 2016 Published: 30 April 2017

\begin{abstract}
Purpose: This paper examines the spatial heterogeneity associated with broadband Internet and new firm formation in a number of U.S. states.

Methodology/Approach: Both ordinary least-squares regression and Geographically Weighted Regression are used for the estimation purpose.

Findings: The global coefficient estimates of ordinary least-squares regression account for the marginal change in a phenomenon, but such a global measure cannot reveal the locally-varying dynamics. Using Geographically Weighted Regression, it was found that at the aggregate and economic sector levels, the association between single-unit firm births and the provision of broadband Internet varies across counties in Florida and Ohio.

Originality/Value of paper: There are numerous studies on broadband Internet in the U.S., but this is the first that explicitly examines broadband provision and new firm formation by taking into account spatial heterogeneity across countries.
\end{abstract}

Category: Research paper

Keywords: broadband Internet; new firm formation; spatial heterogeneity; geographically weighted regression; regional economy

\section{BACKGROUND}

Both hard and soft infrastructure (Haynes, 2006) are capital stocks of a nation or region (Nijkamp, 1986; Prud'homme, 2005) and generally impact economic growth and development positively. However, a dam becomes useful only after it is fully operational, a sewer system in a region cannot be useful to another region, or a natural monopoly can easily distort the market. That is, infrastructure's inherent characteristics, such as lumpiness, space-specificity, and 
market failure (see Gomez-Ibanez, 2003; Prud'homme, 2005), often limit its effectiveness.

The Internet as a General Purpose Technology (GPT) is an important infrastructure in today's business environment (Bresnahan and Trajtenberg, 1995; David and Wright, 2003; Lipsey, Carlaw and Bekar, 2005; Ruttan, 2008). Businesses can collect, share, and disseminate information irrespective of distance and time as well as offer innovative solutions and recruit employee online (Angelides, 1997; Cappelli, 2001; Sharma, 2002). A real-time, collaborative environment helps to generate new capabilities, markets, and strategies that are important for growth (Austin and Bradley, 2005) and network (see Katz and Shapiro, 1985) and scale effects (see Arthur, 1990) increase the utility and value of a network. For instance, information networks as GPTs facilitate trade and factor service of skilled labor (Harris, 1998). Majumdar, et al. (2010) further noted that broadband Internet as a GPT positively influences the productivity of the firms by enabling better communications, high-speed business transactions, and efficient organization of production activities. In addition, since its commercialization, the Internet has offered not only virtual business models, such as Amazon.com, Craiglist, and eBay, but also compelled traditional businesses like Walmart, Toys R Us, Walgreens, Dell, and FedEx to adopt Webbased strategies for sales and services (Bakos, 1998; Griffith and Krampf, 1998). Small and medium enterprises are also making virtual presence a strategic necessity (Grandon and Pearson, 2004).

This paper proposes that because the Internet offers various business possibilities, entrepreneurs that render innovation into economic opportunities (Schumpeter, 1942) are likely to be attracted to regions that have broadband Internet infrastructure. Thus, in order to examine the relationship between new firm formation and the provision of broadband, two methods will be adopted. First, as with the earlier study (Parajuli and Haynes, 2012), with counties as the observation units, ordinary least-squares (OLS) models will be estimated for a number of U.S. states at the aggregate and economic sector levels. Second, since firm births are not consistent across counties and that spatial heterogeneity is likely to be observed, Geographically Weighted Regression (GWR) models will be calibrated. While the OLS estimates will give the global relationship, the GWR estimates will provide the local relationship for counties embedded in states.

\section{LITERATURE REVIEW AND RESEARCH HYPOTHESES}

While entrepreneurs are instrumental in innovation, job and wealth creation, productivity, positive spillovers, and alternate opportunities (Malecki, 1994; Acs 2006; Van Praag and Versloot, 2007), the entrepreneurial spirit is often influenced by physical and virtual networks (Florida, 1995; Nijkamp, 2003). Innovations are concentrated in regions with technological infrastructure (Feldman and Florida, 1994). In addition, producers (Fujita, Krugman and 
Venables, 1999), foreign multinationals (Friedman, Gerlowski and Silberman, 1992), and new businesses (Holl, 2004) are located in a close proximity of transportation infrastructure. Moreover, information and communications technology (ICT) infrastructure not only permits innovations, but also selfreinforces new innovations (McQuaid, 2002). Based on these findings, the first research hypothesis is that new firm formation is positively related to the provision of broadband infrastructure.

According to Acs and Armington (2006), population growth functions as both supply and demand variables with reference to the entrepreneurial activities. As the population grows in a region, it supplies potential entrepreneurs, and also increases the demand of goods and services. Thus, regional variation in new firm formation is positively influenced by population growth (Guesnier, 1994; Reynolds, Miller and Maki, 1995; Armington and Acs, 2002; Acs and Armington, 2006). Sutaria and Hicks (2004), on the contrary, found that population growth was not positively significant in explaining new firm formation. However, they accepted the modeling limitations that could not capture the expected (positive) relationship between new firm formation and population growth. This leads to the second research hypothesis that new firm formation and population growth are positively related.

Innovative ideas and a higher disposable income are likely to foster business ventures. Butler and Herring (1991) noted that individuals that have access to a higher family income are likely to have higher employment opportunities. Armington and Acs (2002) and Lee, Florida and Acs (2004) observed a positive association between income growth and new firm births. Likewise, Reynolds, Miller and Maki (1995) found that the presence of greater personal wealth and firm formation are positively related to each other. That new firm formation and income growth are positively related is the third hypothesis.

A large firm is often dependent on smaller firms for specialty goods and services. This could be the reason why Sutaria and Hicks (2004) found a positive relationship between firm size and new firm births. However, Fritsch and Falck (2002) and Armington and Acs (2002) observed a negative association between firm size and firm formation. The negative association could be due to the existence of large firms and/or their branches that hinder new firm births (Armington and Acs, 2002). The fourth hypothesis is that new firm formation and mean establishment size are negatively associated.

Although the effect of unemployment is small, regions that have a higher unemployment level experience higher firm births. Reynolds, Miller and Maki (1995 and Acs (2006) suggested that as individuals cannot find jobs, they start new businesses as an act of necessity and desperation. Storey (1991) and Audretsch and Fritsch (1994) found both positive and negative associations; Sutaria and Hicks (2004) found a negative association; and Fritsch and Falck (2002) found no relationship between firm formation and unemployment. Since there is no clear understanding of the relationship between employment rate and 
new firm formation, the fifth hypothesis is that there is a relationship between new firm births and the unemployment rate, but the direction of the relationship is indeterminate.

Financial capital that entrepreneurs accrue from various sources, such as personal savings, social contacts, venture capital organizations, and banks, is necessary for starting and sustaining nascent firms over time. In general, individuals with embedded relationships and networks in a local environment are most likely to get seed and long-term capital (Uzzi, 1999; Gompers and Lerner, 2001). Sutaria and Hicks (2004) noted that new firm formation is positively associated with the availability of local financial capital. In addition, Cooper, Gimeno-Gascon and Woo (1994) found that the level of capitalization contributes to the survival and growth of new business ventures. The next research hypothesis then is that new firm formation and the availability of local financial capital are positively related.

Government spending can have mixed effects on new firm formation. Entrepreneurs are often willing to sacrifice low initial earnings, but findings may be quite different in highly paid and less stressful work environments (Hamilton, 2000). If well-paid and less stressful (government) jobs are readily available, individuals might be attracted to them instead of pursuing innovation and selfemployment. In addition, government investment crowds out private investment in the long-run (Spencer and Yohe, 1970) and government pork-barrel spending simply advances the reelection agenda of politicians instead of contributing to development (Cadot, Roller and Stephan, 2006). On the contrary, public spending in infrastructure is positive and significantly related to productivity (Aschauer, 1989; Munnell, 1990). Government contracts and welfare payments can also increase demand for new goods and services in region and create new business possibilities. Thus, the next hypothesis is that there exists a relationship between new firm formation and government spending, but the direction of the relationship is uncertain.

Saxenian (2002) and Hart and Acs (2011) suggested that regions that are culturally diverse are attractive to entrepreneurs. Lee, Florida and Acs (2004) and Audretsch, Dohse and Niebuhr (2010) found a significant positive relationship between cultural diversity and firm births. Thus, the eights hypothesis is that there exists a positive relationship between new firm formation and cultural diversity.

Spatial structures play an important role in regional economic activities (Markusen, 1996; Krugman, 1998; Fujita, Krugman and Venables, 1999). Knowledge spillover is more in cities where local competition and urban variety encourages employment growth (Glaeser, et al., 1992). Further, new businesses form in clusters that supply specialized inputs and require specialized infrastructure (Porter, 2000). Hence, agglomeration economies are important for entrepreneurial ventures (Acs and Varga, 2005). This leads to the hypothesis that diversified and agglomerated metro regions compared to non-metro regions are more likely to be attractive to new firms. 
Spatial heterogeneity is associated with the spatially varying phenomenon. According to Lomi (1995), regional level analysis compared to national level analysis provides a better understanding of organizational founding and that neglecting the heterogeneity effects tend to overestimate the effects of founding rates. Stuart and Sorenson (2003), Li, et al. (2011), and Cheng and Li (2011) observed the variation in firm formation as well as employment generation in smaller regions embedded in a large region. We believe that this means it is necessary to do a lower level assessment to capture these issues of potential spatial heterogeneity. Hence, we explore the issue of heterogeneity at the county level.

\section{RESEARCH DESIGN AND DATA}

A global multiple regression model is given as:

$$
y_{i}=\beta_{0}+\sum_{k} \beta_{k} x_{i k}+\varepsilon_{i}
$$

where $y$ is the dependent variable, $x$ 's are the independent variables, $\beta$ 's are the parameters to be estimated, and $\varepsilon$ is the independent and identically distributed error term with zero mean and a constant variance. The subscript $i$ denotes the number of observations and $k$ the number of independent variables.

By extending the global model given by Equation (1), the GWR model is written as:

$$
y_{i}=b_{0}\left(u_{i}, v_{i}\right)+\sum_{k} b_{k}\left(u_{i}, v_{i}\right) x_{i k}+\varepsilon_{i}
$$

where $\left(u_{i}, v_{i}\right)$ denotes the coordinates of point $i$ in space and $b_{k}\left(u_{i}, v_{i}\right)$ is the realization of the continuous function $b_{k}(u, v)$ at point $i$ (Brunsdon, Fotheringham and Charlton, 1996; Fotheringham, Charlton and Brunsdon, 1998). This transformation allows us to estimate local parameters that vary across space.

Using the matrix notation, the coefficients in Equation (1) are estimated by:

$$
\widehat{\boldsymbol{\beta}}=\left(\boldsymbol{X}^{T} \boldsymbol{X}\right)^{-1} \boldsymbol{X}^{T} \boldsymbol{y}
$$

However, for Equation (2), the coefficient estimates are:

$$
\widehat{\boldsymbol{b}}\left(u_{i}, v_{i}\right)=\left[\boldsymbol{X}^{T} \boldsymbol{W}\left(u_{i}, v_{i}\right) \boldsymbol{X}\right]^{-1} \boldsymbol{X}^{T} \boldsymbol{W}\left(u_{i}, v_{i}\right) \boldsymbol{y}
$$


where for a sample size of $n, \boldsymbol{W}\left(u_{i}, v_{i}\right)$ is a weight matrix of size $(n \times n)$ whose off-diagonal elements are zero and diagonal elements denote the geographical weighting of observed data for point $i$. Because of the weight matrix, the estimators are the weighted least-squares estimators. In addition, $\mathrm{T}$ and -1 denote the transposition and inversion of matrix, respectively.

The weight matrix, $\boldsymbol{W}$, is specified as a distance-decay function. In order to estimate the local parameters for a location $i$, the weight is given by:

$$
w_{i j}=\exp \left(\frac{d_{i j}^{2}}{B^{2}}\right)^{-1}
$$

where $j$ is another point in space, $d_{i j}$ is the distance between $i$ and $j$, and $B$ is the bandwidth of the kernel density function. At the regression point $i$, the weight is unity and decreases with distance. This implies that observations near $i$ influence parameter estimation more than observations farther away from $i$. $B$ can be fixed or adaptive based on the nature of kernel function and can be selected using a cross-validation approach or the Akaike Information Criterion (AIC) approach (Brunsdon, Fotheringham and Charlton, 1996; Fotheringham, Charlton and Brunsdon, 1998). Further, according to Fotheringham, Brunsdon and Charlton (2002), AIC can be used for selecting the true model from the competing models. The model with the smallest AIC value provides a better fit and the models are genuinely different if the improvement is greater than 3 .

While the method of GWR allows for calibrating local parameters, it has a number of limitations. First, GWR regression estimates are sensitive to weighting schemes and bandwidth selection, and sample size. This often leads to less accurate estimates than OLS estimates. Second, the number of GWR coefficient estimates is large compared to the number of OLS estimates. Thus, it is not only computationally intensive, but also makes it difficult to report on all GWR estimates. Third, since samples overlap during the estimation and statistical analysis, the results should be treated with caution (see Ali, Partridge and Olfert, 2007; Li, et al., 2011).

Data for the study come from various sources. The raw, non-public single-unit firm births data are from the Census Bureau (CB). For 2006, the county level dataset contains single-unit firm births across the five-digit North American Industry Classification System (NAICS). The Federal Communications Commission (FCC) provides the number of high-speed service providers by zip codes. The raw data includes the number of holding companies that reported providing high-speed Internet service to at least one customer in the zip code of interest. If there are one to three companies reporting services to at least one customer in a zip code, the FCC does not report the number of service providers in that particular zip code, but indicates some provision exists.

The number of service providers at each zip code will be matched to its respective county by using the information on Zip Code Tabulation Area 
(ZCTA). The online tool called Dexter provided by Missouri Census Data Center (MCDC) is used for matching zip codes and ZCTAs. Assuming that new firms will have a wide range of broadband choices in terms of price and services, for the provision of broadband in each county, the maximum number of broadband provider for 2006 will be used as the proxy for broadband access.

Population growth is the percentage change in population and personal income growth in the percentage change in per capita income from 2005 to 2006. Both of these indicators are obtained from the Bureau of Economic Analysis (BEA). Mean establishment size is the average number of employees in a firm in 2006 and is obtained from the CB. Other variables obtained from the CB include per capita deposit in dollars in local commercial and savings institutions in 2005 and serves as a proxy for locally available financial capital; per capita federal spending in dollars in 2006 indicates an additional source of capital; and the share of white population as a percentage of total population in 2006 is our negative proxy for diversity.

The unemployment rate, which is the share of unemployed labor force in percentage, is for 2006 and is obtained from the Bureau of Labor Statistics (BLS). Rural-urban continuum, which is available from the United States Department of Agriculture (USDA), is a categorical variable based on population size and ranges from 1 to 9. A dummy variable "metro" will be created using this categorical variable to separate metro (1 to 3) and nonmetro (4 to 9) counties.

Tab. 1 summarizes variables, their descriptions, expected signs based on research hypotheses, and data sources. Since firm births and the number of maximum providers are highly skewed, they are converted to their logarithmic equivalents and denoted by "logsub" and "logmxprov," respectively, in the OLS and GWR models.

\section{Table 1 - Variable description}

\begin{tabular}{|c|c|c|c|}
\hline Variable & Description & Expected sign & Source \\
\hline \multicolumn{4}{|l|}{ Dependent variable } \\
\hline Firm birth (sub) & Number of single-unit firm births in 2006 & & \\
\hline \multicolumn{4}{|l|}{ Independent variables } \\
\hline $\begin{array}{l}\text { Broadband providers } \\
\text { (mxprov) }\end{array}$ & $\begin{array}{l}\text { Maximum number of broadband service } \\
\text { providers in } 2006\end{array}$ & + & FCC \\
\hline Population growth (popgr) & $\begin{array}{l}\text { Population change from } 2005 \text { to } 2006 \text { (in } \\
\text { percentage) }\end{array}$ & + & BEA \\
\hline $\begin{array}{l}\text { Personal income growth } \\
\text { (perincgr) }\end{array}$ & $\begin{array}{l}\text { Per capita income change from } 2005 \text { to } \\
2006 \text { (in percentage) }\end{array}$ & + & BEA \\
\hline $\begin{array}{l}\text { Establishment size } \\
\text { (estsize) }\end{array}$ & $\begin{array}{l}\text { Mean number of employees in a firm in } \\
2006\end{array}$ & - & $\mathrm{CB}$ \\
\hline $\begin{array}{l}\text { Unemployment rate } \\
\text { (unemprt) }\end{array}$ & $\begin{array}{l}\text { Share of unemployed labor force in } 2006 \\
\text { (in percentage) }\end{array}$ & $?$ & BLS \\
\hline Financial capital (fincap) & $\begin{array}{l}\text { Per capita deposit in local commercial } \\
\text { and savings institutions in } 2005 \text { (in } \\
\text { thousand dollars) }\end{array}$ & + & $\mathrm{CB}$ \\
\hline Federal spending (fedspnd) & $\begin{array}{l}\text { Per capita federal spending in } 2006 \text { (in } \\
\text { thousand dollars) }\end{array}$ & $?$ & $\mathrm{CB}$ \\
\hline
\end{tabular}




\begin{tabular}{|l|l|c|r|}
\hline \multicolumn{1}{|c|}{ Variable } & \multicolumn{1}{|c|}{ Description } & Expected sign & Source \\
\hline White (white) & $\begin{array}{l}\text { Share of whites in total population in } \\
\text { 2006 (in percentage) }\end{array}$ & - & CB \\
\hline $\begin{array}{l}\text { Rural-urban continuum } \\
\text { (metro) }\end{array}$ & $\begin{array}{l}\text { Rural-urban classification based on } \\
\text { population size }(1=\text { metro counties and 0 } \\
\text { nonmetro counties) }\end{array}$ & + & USDA \\
\hline
\end{tabular}

\section{EMPIRICAL FINDINGS}

In an earlier study (Parajuli and Haynes, 2012), eight states - Colorado, Florida, Montana, New Jersey, Ohio, Oregon, South Carolina, and Wisconsin - were randomly sampled from the 48 contiguous U.S. states. In the aggregate level analysis, the association between the total number of new firm births and the maximum provision of broadband was examined using multiple regression models. Total new firm births in each sampled state were also disaggregated by the 2-digit NAICS codes and the same set of hypotheses was tested for the manufacturing (NAICS 31-33), finance and insurance (NAICS 52), and real estate and rental and leasing (NAICS 53) sectors. In general, the association between single-unit firm births and the provision of broadband was positive and statistically significant across sampled states at the aggregate and economic sector levels. Because of the space and data limitation, this paper only presents analyses of Florida and Ohio at both the aggregate and economic sector levels. Sectoral analyses are carried out for the construction (NAICS 23) and retail trade (NAICS 44-45) sectors.

In 2006, the association between new firm formation and the maximum number of service providers that reported providing high-speed (Internet) service to at least one customer for Florida and Ohio was 0.6572 and 0.5052 , respectively, and that these values were statistically significant at the $5 \%$ level of significance. As an example, in Florida, while Broward, Hillsborough, Miami-Date, and Seminole counties had the largest number of operators (19), Franklin County had at most five operators providing services to at least one customer. The counties with a large number of service providers also experienced a large number of new firm births - 7,571 (Broward), 3,770 (Hillsborough), 9,793 (Miami-Dade), 1,733 (Seminole). On the contrary, Franklin County had only 29 new firm births.

Table 2 - Multiple regression models, Aggregate (Source: Authors' calculations)

\begin{tabular}{|c|c|c|}
\hline & OLS (Florida) & OLS (Ohio) \\
\hline \multirow[t]{2}{*}{ logmxprov } & $3.7655^{* * *}$ & $0.7714^{* *}$ \\
\hline & $(0.3198)$ & $(0.3509)$ \\
\hline \multirow[t]{2}{*}{ popgr } & 0.0336 & 0.1042 \\
\hline & $(0.0331)$ & $(0.0754)$ \\
\hline \multirow[t]{2}{*}{ perincgr } & -0.0007 & 0.0538 \\
\hline & $(0.0321)$ & $(0.0423)$ \\
\hline \multirow[t]{2}{*}{ estsize } & $-0.0451^{* * *}$ & $-0.0594^{* * *}$ \\
\hline & $(0.0167)$ & $(0.0169)$ \\
\hline
\end{tabular}




\begin{tabular}{|l|r|r|}
\hline & OLS (Florida) & OLS (Ohio) \\
\hline unemprt & 0.0271 & $-0.1353^{* *}$ \\
\hline & $(0.1123)$ & $(0.0648)$ \\
\hline fincap & $0.0401^{* *}$ & -0.0112 \\
\hline & $(0.0162)$ & $(0.0165)$ \\
\hline fedspnd & $-0.0464^{*}$ & -0.0230 \\
\hline & $(0.0271)$ & $(0.0149)$ \\
\hline white & -0.0035 & $-0.0890^{* * *}$ \\
\hline & $(0.0081)$ & $(0.0149)$ \\
\hline metro & 0.1138 & $0.6085^{* * *}$ \\
\hline & $(0.2127)$ & $(0.1507)$ \\
\hline Constant & $-2.7391^{* *}$ & $12.9785^{* * *}$ \\
\hline & $(1.2385)$ & $(2.1863)$ \\
\hline Observations & 67 & 88 \\
\hline Adjusted-R2 & 0.9062 & 0.7696 \\
\hline Significant at ${ }^{*} p<0.1$ level, ${ }^{* *} p<0.05$ level, and ${ }^{* * *} p<0.01$ level; Standard errors in parentheses. \\
\hline
\end{tabular}

As shown in Tab. 2, in Florida, after controlling for other variables, for a $1 \%$ increase in the provision of broadband services, there was almost $3.8 \%$ increase in the single-unit firm births. In Ohio, the estimated coefficient of the maximum number of providers was positive and statistically significant, but the association between new firm formation and the provision of broadband was relatively smaller compared to Florida. Since the coefficient estimates are consistent with the expectation, this suggests that new firms are attracted to regions that have broadband provision.

The significance of other coefficient estimates, however, varies across models. In Florida, the mean establishment size is negative and statistically significant. These findings are consistent with Armington and Acs (2002) and Fritsch and Falck (2002). The coefficient of the availability of financial capital is positive and of federal spending is negative and statistically significant. Sutaria and Hicks (2004) had found a positive relationship between local bank deposit per capita and new firm formation. Although our expectation with the association between federal spending and new firm births was indeterminate, we found a negative and statistically significant association between them. This could have resulted due to the availability of well-paid jobs in the government sector, complacency among individuals due to grants and retirement spending, or crowding out of private investment by government spending as noted by Hamilton (2000) and Spencer and Yohe (1970).

In Ohio, mean establishment size, unemployment rate, and "white" as a proxy of diversity, were negatively associated with single-unit firm births. Our findings are consistent with Sutaria and Hicks (2004) in relation to financial capital and Audretsch, Dohse and Niebuhr (2010) and Lee, Florida and Acs (2004) in relation to diversity and new firm formation. Although the expected sign of the coefficient of unemployment rate was not obvious, it was found that in Ohio 
there is a negative relationship between unemployment rate and new firm births and this finding is consistent with Sutaria and Hicks (2004).

In order to examine spatial heterogeneity, GWR models were calibrated using the spgwr package in R. Bandwidth of the fixed Gaussian kernel function was selected using the cross-validation approach and AIC scores were used for comparing the fit of models.

Table 3 - OLS and GWR models, Aggregate, Florida (Source: Authors' calculations)

\begin{tabular}{|c|c|c|c|c|c|c|}
\hline & \multirow[t]{2}{*}{ OLS } & \multicolumn{5}{|c|}{ GWR } \\
\hline & & Min. & 1st quar. & Median & 3rd quar. & Max. \\
\hline logmxprov & $3.7655^{* * * *}$ & 3.3400 & 3.7570 & 3.7020 & 3.8470 & 3.9730 \\
\hline popgr & 0.0336 & 0.0294 & 0.0314 & 0.0329 & 0.0354 & 0.0372 \\
\hline perincgr & -0.0007 & -0.0117 & 0.0012 & 0.0094 & 0.0190 & 0.0265 \\
\hline estsize & $-0.0451^{* * *}$ & -0.0529 & -0.0515 & -0.0483 & -0.0454 & -0.0412 \\
\hline unemprt & 0.0371 & -0.0144 & 0.0232 & 0.0406 & 0.0483 & 0.0533 \\
\hline fincap & $0.0401^{* *}$ & 0.0319 & 0.0327 & 0.0335 & 0.0351 & 0.0408 \\
\hline fedspnd & $-0.0464^{*}$ & -0.0522 & -0.0390 & -0.0352 & -0.0337 & -0.0284 \\
\hline white & -0.0035 & -0.0183 & -0.0071 & -0.0032 & 0.0006 & 0.0055 \\
\hline metro & 0.1138 & 0.0880 & 0.1059 & 0.1219 & 0.1444 & 0.2199 \\
\hline Constant & $-2.7391^{* *}$ & -2.8350 & -2.7180 & -2.6520 & -2.5180 & -1.6750 \\
\hline Observations & 67 & \multicolumn{5}{|c|}{67} \\
\hline Number of nearest neighbors & & \multicolumn{5}{|c|}{3} \\
\hline AIC & 116.55 & \multicolumn{5}{|c|}{98.68} \\
\hline
\end{tabular}

Tab. 3 shows the results of OLS and GWR models at the aggregate level for Florida. Based on cross-validation, it was found that for a regression point i only three nearest neighbouring counties have non-zero weights and that the weight decrease with the distance. Unlike the global OLS estimates, GWR estimates vary across counties. For instance, the global estimate of the provision of broadband is 3.76. However, the local estimates based on GWR vary from 3.34 to 3.97 and is shown in Fig. 1. Similarly, the goodness-of-fit values of the GWR model vary across counties and are shown in Fig. 2. 
Legend

$$
\begin{aligned}
& 3.3403-3.5397 \\
& 3.5397-3.6486 \\
& 3.6486-3.7661 \\
& 3.7661-3.8702 \\
& 3.8702-3.9728
\end{aligned}
$$

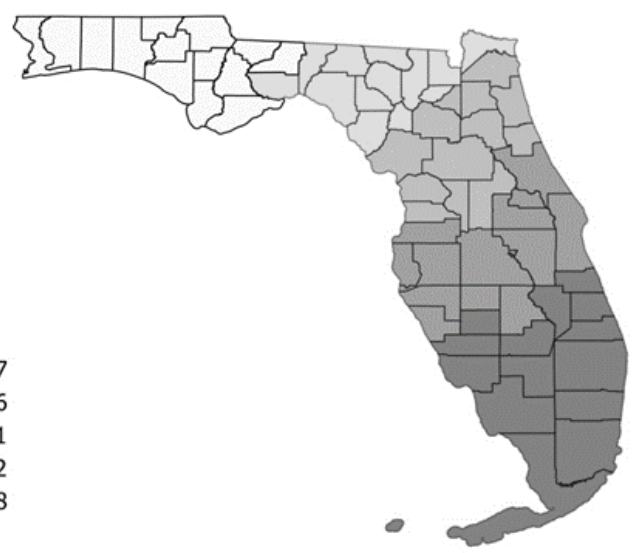

Figure 1-GWR estimates of the provision of broadband, Aggregate, Florida (Source: Authors' calculations)
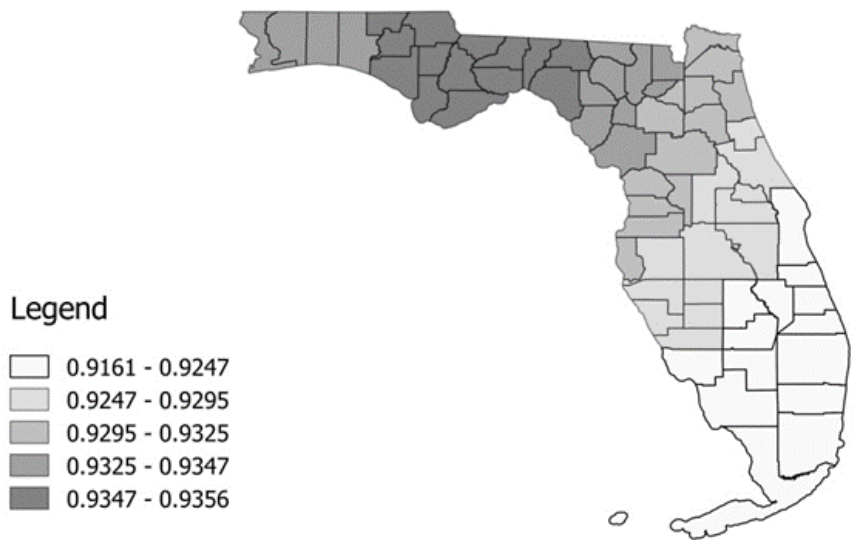

Figure 2 - Local R-squared values, Aggregate, Florida (Source: Authors' calculations)

The AIC value of GWR model (98.68) is smaller than the AIC value of OLS model (116.55). Thus, GWR model does not only reveal the local heterogeneity, but also provides a better fit compared to OLS model.

Tab. 4 shows the OLS and GWR estimates of Ohio at the aggregate level. As with the estimates of Florida, the GWR estimates of Ohio vary across counties. The larger AIC value of GWR model compared to OLS model suggests that GWR provides a better fit. 
Table 4-OLS and GWR models, Aggregate, Ohio (Source: Authors' calculations)

\begin{tabular}{|c|c|c|c|c|c|c|}
\hline & OLS & \multicolumn{5}{|c|}{ GWR } \\
\hline & & Min. & 1st quar. & Median & 3rd quar. & Max. \\
\hline logmxprov & $0.7714^{* *}$ & 0.1891 & 0.6316 & 0.9209 & 1.2590 & 1.7950 \\
\hline popgr & 0.1042 & -0.0430 & 0.0405 & 0.0980 & 0.1421 & 0.1986 \\
\hline perincgr & 0.0538 & 0.0251 & 0.0451 & 0.0622 & 0.0961 & 0.1365 \\
\hline estsize & $-0.0594^{* * * *}$ & -0.0642 & -0.0560 & -0.0484 & -0.0432 & -0.0379 \\
\hline unemprt & $-0.1353^{* *}$ & -0.2228 & -0.1824 & -0.1272 & -0.1042 & -0.0360 \\
\hline fincap & -0.0112 & -0.0201 & -0.0127 & -0.0098 & -0.0077 & -0.0033 \\
\hline fedspnd & -0.0230 & -0.0629 & -0.0281 & -0.0179 & -0.0152 & -0.0005 \\
\hline white & $-0.0880^{* * * *}$ & -0.0983 & -0.0944 & -0.0884 & -0.0811 & -0.0766 \\
\hline metro & $0.6085^{* * *}$ & 0.2746 & 0.4292 & 0.4887 & 0.5303 & 0.6540 \\
\hline Constant & $12.9785^{* * *}$ & 9.9850 & 11.1300 & 12.1100 & 13.2600 & 15.0900 \\
\hline Observations & 88 & \multicolumn{5}{|c|}{88} \\
\hline Number of nearest neighbors & & \multicolumn{5}{|c|}{1} \\
\hline AIC & 152.07 & \multicolumn{5}{|c|}{120.67} \\
\hline Significant at ${ }^{*} p<0.1$ level, & 05 level, & $p<$ & evel & & & \\
\hline
\end{tabular}

The results of OLS and GWR models for the construction sector of Florida are shown in Tab. 5. The fixed Gaussian kernel function gives non-zero weights for two nearest neighbours. In addition, the AIC of the GWR model (104.81) is smaller than that of OLS model (122.64), which suggests that the GWR model provides a better fit compared to OLS model.

Table 5-OLS and GWR models, Construction, Florida (Source: Authors' calculations)

\begin{tabular}{|c|c|c|c|c|c|c|}
\hline & \multirow[t]{2}{*}{ OLS } & \multicolumn{5}{|c|}{ GWR } \\
\hline & & Min. & 1st quar. & Median & 3rd quar. & Max. \\
\hline logmxprov & $3.4271^{* * * *}$ & 3.3460 & 3.3600 & 3.3660 & 3.3800 & 3.3930 \\
\hline popgr & $0.0539^{*}$ & 0.0452 & 0.0493 & 0.0540 & 0.0590 & 0.0683 \\
\hline perincgr & 0.0162 & $\begin{array}{l}-0.0102 \\
\end{array}$ & 0.0103 & 0.0205 & 0.0356 & 0.0565 \\
\hline estsize & $-0.0537^{* * *}$ & -0.0731 & -0.0625 & -0.0536 & -0.0454 & -0.0333 \\
\hline unemprt & -0.0938 & -0.1058 & -0.0813 & -0.0762 & -0.0706 & -0.0619 \\
\hline fincap & 0.0176 & 0.0097 & 0.0116 & 0.0155 & 0.0208 & 0.0317 \\
\hline fedspnd & -0.0291 & -0.0409 & -0.0359 & -0.0337 & -0.0309 & -0.0275 \\
\hline white & 0.0067 & -0.0057 & 0.0038 & 0.0070 & 0.0101 & 0.0125 \\
\hline metro & 0.3672 & 0.3435 & 0.3637 & 0.3722 & 0.3786 & 0.3912 \\
\hline Constant & $-3.8443^{* * *}$ & -4.9560 & -4.3500 & -3.8260 & -3.2680 & -1.9810 \\
\hline Observations & 67 & \multicolumn{5}{|c|}{67} \\
\hline Number of nearest neighbors & & \multicolumn{5}{|c|}{2} \\
\hline AIC & 122.64 & \multicolumn{5}{|c|}{104.81} \\
\hline Significant at ${ }^{*} p<0.1$ level, ${ }^{* *} I$ & level, & ${ }^{*} p<0$ & evel & & & \\
\hline
\end{tabular}


For the logarithm of the maximum number of providers, the OLS estimate is 3.4271. The GWR estimators, however, range from 3.346 to 3.393 and each county has its own estimator as shown in Fig. 3. Since the OLS estimate is larger than the GWR estimates, it suggests that OLS overestimated the coefficient of the provision of broadband. The local goodness-of-fit values are shown in Fig. 4. These values are not directly comparable with the global R-squared value, but still suggest the variation in new firm formation explained by the independent variables in the GWR model.

Legend
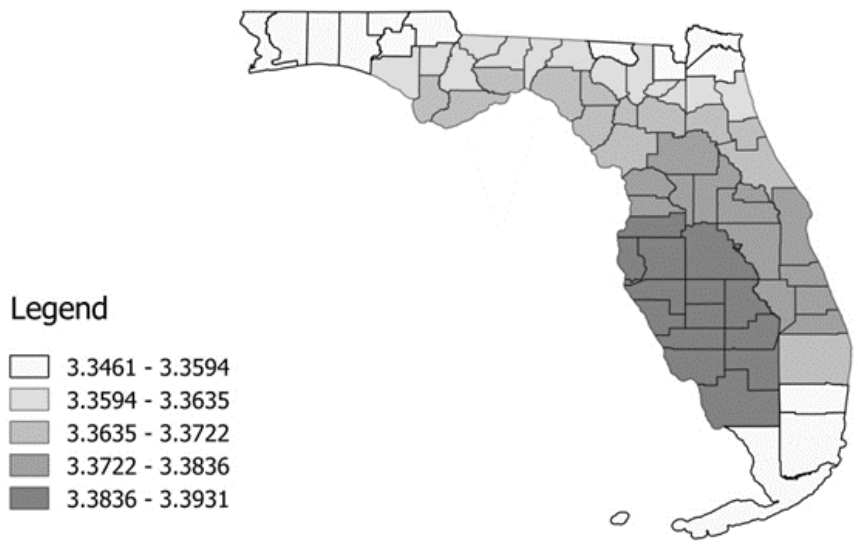

Figure 3-GWR estimates of the provision of broadband, Construction, Florida (Source: Authors' calculations)

Legend
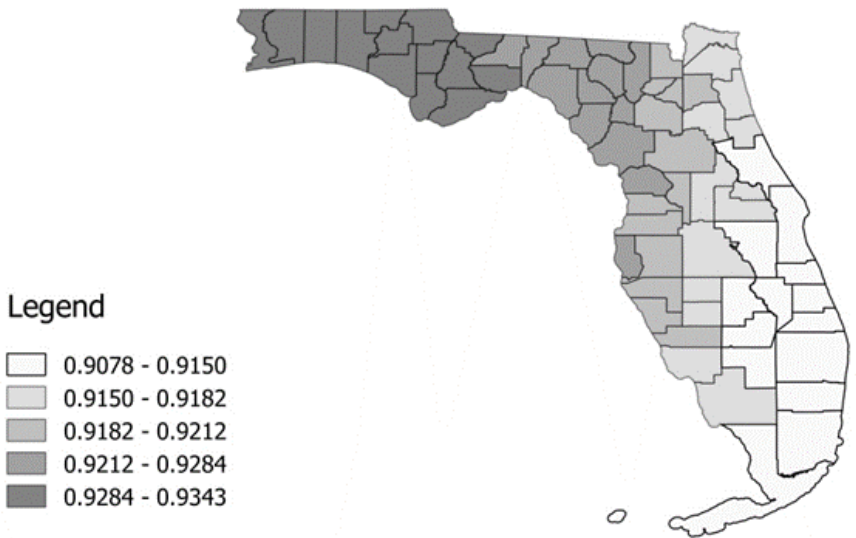

Figure 4 - Local R-squared values, Construction, Florida (Source: Authors' calculations)

Similarly, for the retail trade sector of Florida, the results of OLS and GWR models are shown in Tab. 6. While the OLS coefficient estimate is 3.8803, the GWR estimates of the logarithm of the maximum number of providers ranges 
from 3.5630 to 4.1510. The AIC value of 130.40 associated with the GWR model suggests that it is a better fit in explaining the variation in single-unit firm births compared to the OLS model. Fig. 5 and Fig. 6 show the distribution of the GWR coefficient estimates of the service provision and local goodness-of-fit, respectively. As before, both these figures suggest that estimators and R-squared values vary spatially.

Table 6-OLS and GWR models, Retail trade, Florida (Source: Authors' calculations)

\begin{tabular}{|c|c|c|c|c|c|c|}
\hline & OLS & \multicolumn{5}{|c|}{ GWR } \\
\hline & & Min. & 1st quar. & Median & 3rd quar. & Max. \\
\hline logmxprov & $3.8808^{* * * *}$ & 3.5630 & 3.6890 & 3.8080 & 3.9740 & $\overline{4.1510}$ \\
\hline popgr & 0.0445 & 0.0270 & 0.0344 & 0.0405 & 0.0525 & 0.0705 \\
\hline perincgr & -0.0258 & -0.0292 & -0.0214 & -0.0182 & -0.0160 & -0.0147 \\
\hline estsize & $-0.0356^{*}$ & -0.0471 & -0.0442 & -0.0407 & -0.0348 & -0.0285 \\
\hline unemprt & 0.0689 & 0.0153 & 0.0562 & 0.0736 & 0.0838 & 0.0907 \\
\hline fincap & $0.0490^{* *}$ & 0.0374 & 0.0390 & 0.0403 & 0.0434 & 0.0558 \\
\hline fedspnd & -0.0534 & -0.0560 & -0.0510 & -0.0444 & -0.0400 & -0.0303 \\
\hline white & -0.0097 & -0.0193 & -0.0103 & -0.0080 & -0.0074 & -0.0071 \\
\hline metro & 0.0501 & -0.0580 & -0.0166 & -0.0267 & 0.0981 & 0.3034 \\
\hline Constant & $-4.9709^{* * *}$ & -5.0650 & -4.9310 & -4.8000 & -4.6480 & -4.9709 \\
\hline Observations & 67 & \multicolumn{5}{|c|}{67} \\
\hline Number of nearest neighbors & & \multicolumn{5}{|c|}{4} \\
\hline AIC & 146.04 & \multicolumn{5}{|c|}{130.40} \\
\hline Significant at ${ }^{*} p<0.1$ level, ${ }^{*}$ & 5 level, a & $*^{* * * *} p<0$ & evel & & & \\
\hline
\end{tabular}

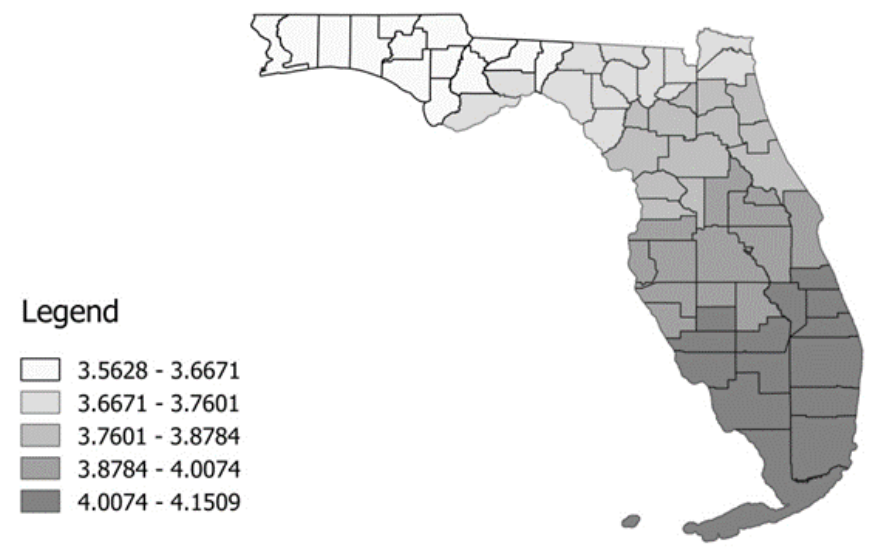

Figure 5 - GWR estimates of the provision of broadband, Retail trade, Florida (Source: Authors' calculations) 


\section{Legend}
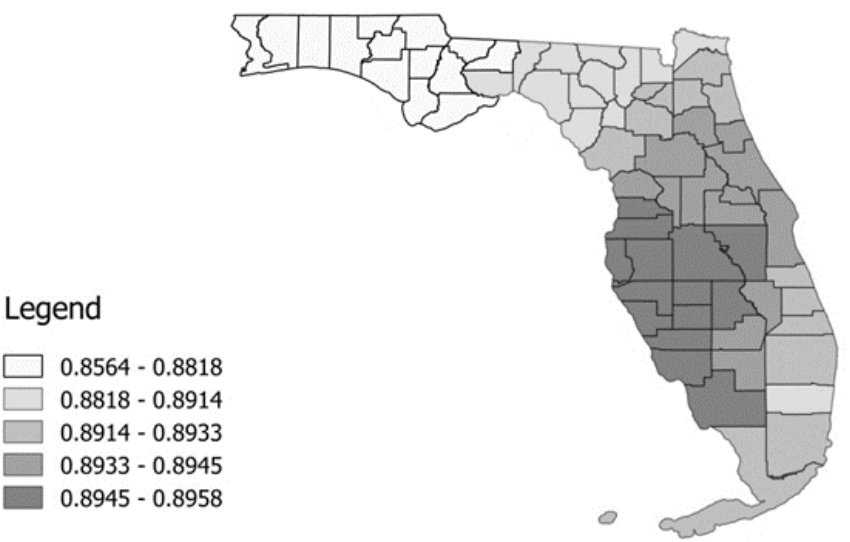

Figure 6-Local R-squared values, Retail trade, Florida (Source: Authors' calculations)

Table 7 - OLS and GWR models, Construction, Ohio (Source: Authors' calculations)

\begin{tabular}{|c|c|c|c|c|c|c|}
\hline & OLS & \multicolumn{5}{|c|}{ GWR } \\
\hline & & Min. & 1st quar. & Median & 3rd quar. & Max. \\
\hline logmxprov & 0.1988 & -0.3334 & -0.0197 & 0.2690 & 0.9449 & 1.8580 \\
\hline popgr & 0.0359 & -0.1976 & -0.0659 & 0.0456 & 0.1178 & 0.1637 \\
\hline perincgr & -0.0045 & -0.0253 & -0.0038 & 0.0135 & 0.0277 & 0.0664 \\
\hline estsize & $-0.0485^{* *}$ & -0.0572 & -0.0440 & -0.0334 & -0.0262 & -0.0146 \\
\hline unemprt & $-0.2260^{* * *}$ & -0.3794 & -0.2871 & -0.1994 & -0.1614 & -0.1015 \\
\hline fincap & -0.0030 & -0.0146 & -0.0052 & 0.0008 & 0.0069 & 0.0132 \\
\hline fedspnd & -0.0274 & -0.0492 & -0.0343 & -0.0292 & -0.0176 & 0.0391 \\
\hline white & $-0.0780^{* * * *}$ & $\begin{array}{l}-0.0931 \\
\end{array}$ & -0.0874 & -0.0790 & $\begin{array}{l}-0.0628 \\
\end{array}$ & -0.0502 \\
\hline metro & $0.8290^{* * *}$ & 0.3957 & 0.6058 & 0.7360 & 0.7850 & 0.8379 \\
\hline Constant & $11.6452^{* * *}$ & 5.7290 & 8.5370 & 11.0600 & 12.1400 & 13.0100 \\
\hline Observations & 88 & \multicolumn{5}{|c|}{88} \\
\hline Number of nearest neighbors & & \multicolumn{5}{|c|}{1} \\
\hline AIC & 191.16 & \multicolumn{5}{|c|}{156.04} \\
\hline
\end{tabular}

Table 8-OLS and GWR models, Retail trade, Ohio (Source: Authors' calculations)

\begin{tabular}{|l|r|r|r|r|r|c|}
\hline & \multicolumn{1}{|c|}{ OLS } & \multicolumn{5}{|c|}{ GWR } \\
\hline & & \multicolumn{1}{c|}{ Min. } & \multicolumn{1}{c|}{ 1st quar. } & \multicolumn{1}{c|}{ Median } & 3rd quar. & \multicolumn{1}{c|}{ Max. } \\
\hline logmxprov & $1.0514^{* *}$ & 0.6087 & 0.8139 & 1.1050 & 1.4860 & 2.0620 \\
\hline popgr & 0.0691 & -0.0866 & 0.0042 & 0.0634 & 0.1048 & 0.1437 \\
\hline perincgr & 0.0551 & 0.0349 & 0.0625 & 0.0837 & 0.1141 & 0.1391 \\
\hline estsize & $-0.0552^{* *}$ & -0.0687 & -0.0551 & -0.0491 & -0.0412 & -0.0247 \\
\hline
\end{tabular}




\begin{tabular}{|c|c|c|c|c|c|c|}
\hline \multirow[b]{2}{*}{ unemprt } & \multirow{2}{*}{$\begin{array}{l}\text { OLS } \\
-0.0368\end{array}$} & \multicolumn{5}{|c|}{ GWR } \\
\hline & & -0.1334 & -0.0937 & -0.0352 & -0.0024 & 0.0197 \\
\hline fincap & -0.0232 & -0.0534 & -0.0258 & -0.0217 & -0.0177 & -0.0106 \\
\hline fedspnd & 0.0150 & -0.0526 & 0.0039 & 0.0162 & 0.0277 & 0.0599 \\
\hline white & $-0.0844^{* * *}$ & -0.0910 & -0.0887 & -0.0859 & -0.0773 & -0.0704 \\
\hline metro & $0.5830^{* * *}$ & 0.1798 & 0.3252 & 0.4137 & 0.5164 & 0.6914 \\
\hline Constant & $9.0597^{* * *}$ & 6.0210 & 7.7570 & 8.6996 & 9.2700 & 10.1200 \\
\hline Observations & 88 & \multicolumn{5}{|c|}{88} \\
\hline Number of nearest neighbors & & \multicolumn{5}{|c|}{2} \\
\hline AIC & 203.53 & \multicolumn{5}{|c|}{180.72} \\
\hline
\end{tabular}

Tabs. 7 and 8 show the results of OLS and GWR models of the construction and retail trade sector of Ohio, respectively. These results also suggest that, unlike the global estimates given by the OLS modelling approach, GWR gives locallyvarying coefficient estimates. In both the case, GWR models provide a better fit than OLS models.

\section{CONCLUSION}

This paper examined spatial heterogeneity in relation to broadband Internet and new firm formation using GWR models. The estimates of GWR models were able to capture the spatially-varying effects, which indicated that firm formation and broadband provision are non-stationary. In addition, it was also found that the local models provided better fit compared to the global OLS models at both the aggregate and economic sector levels.

In today's informational economy, while infrastructure such as broadband Internet is important for attracting new firms, which create jobs and contributed to the overall economy, the association between broadband and new firm formation varies spatially. Thus, policy makers need to take into account the local spatial dynamics that are not revealed at the global level while formulating broadband and economic development policies.

In this paper, AIC scores were used for selecting the true model. Based on AIC GWR models were found to be better fits than OLS models, but their differences were not statistically determined. Future research should statistically assess such differences. In addition, new studies should also focus on examining spatial dynamics of broadband Internet and new ventures in other states in the U.S. This would reveal whether or not other states exhibit spatial non-stationary as observed in Florida and Ohio. Spatial regression models, such as spatial lag, spatial error, and spatial Durbin models, can also be calibrated to examine spatial dependence and spillovers. 


\section{ACKNOWLEDGMENTS}

We are grateful to Roger R. Stough at George Mason University for providing the data on firm formation. The authors express their appreciation to the U.S. Department of Agriculture (Award No. 2008-55401-04487) and the U.S. Department of Commerce/Economic Development Agency (Grant No. 99-0713862) for support of this activity. We thank two anonymous reviewers for their constructive feedback and take full responsibility for the analyses and policy interpretations.

\section{REFERENCES}

Acs, Z.J., 2006. How Is Entrepreneurship Good for Economic Growth. Innovations: Technology, Governance, Globalization, 1(1), pp.97-107.

Acs, Z.J. and Armington, C., 2006. Entrepreneurship, Geography, and American Economic Growth. New York, NY: Cambridge University Press.

Acs, Z.J. and Varga, A., 2005. Entrepreneurship, Agglomeration and Technological Change. Small Business Economics, 24(3), pp.323-334.

Ali, K., Partridge, M.D. and Olfert, M.R., 2007. Can Geographically Weighted Regressions Improve Regional Analysis and Policy Making?. International Regional Science Review, 30(3), pp.300-329.

Angelides, M.C., 1997. Implementing the Internet for Business: A Global Marketing Opportunity. International Journal of Information Management, 17(6), pp.405-419.

Armington, C. and Acs, Z.J., 2002. The Determinants of Regional Variation in New Firm Formation. Regional Studies, 36(1), pp.33-45.

Arthur, W.B., 1990. Positive Feedbacks in the Economy. Scientific American, 262(2), pp.92-99.

Aschauer, D.A., 1989. Is Public Expenditure Productive?. Journal of Monetary Economics, 23(2), pp.177-200.

Audretsch, D.B., Dohse, D. and Niebuhr, A., 2010. Cultural Diversity and Entrepreneurship: A Regional Analysis for Germany. Annals of Regional Science, 45(1), pp.55-85.

Audretsch, D.B and Fritsch, M., 1994. The Geography of Firm Births in Germany. Regional Studies, 28(4), pp.359-365.

Austin, R.D. and Bradley, S.P., 2005. The Broadband Explosion. In: R.D. Austin and S.P. Bradley, eds. 2005. The Broadband Explosion: Leading Thinkers on the Promise of a Truly Interactive World. Boston, MA: Harvard Business School Press, pp.3-19. 
Bakos, Y., 1998. The Emerging Role of Electronic Marketplaces on the Internet. Communications of the ACM, 41(8), pp.35-42.

Bresnahan, T.F. and Trajtenberg, M., 1995. General Purpose Technologies 'Engines of Growth'?. Journal of Econometrics, 65(1), pp.83-108.

Brunsdon, C., Fotheringham, A.S. and Charlton, M.E., 1996. Geographically Weighted Regression: A Method for Exploring Spatial Nonstationarity. Geographical Analysis, 28(4), pp.281-298.

Butler, J.S. and Herring, C., 1991. Ethnicity and Entrepreneurship in America: Toward an Explanation of Racial and Ethnic Group Variations in Selfemployment. Sociological Perspectives, 34(1), pp.79-94.

Cadot, O., Roller, L.-H. and Stephan, A., 2006. Contribution to Productivity or Pork Barrel? The Two Faces of Infrastructure Investment. Journal of Public Economics, 90(6-7), pp.1133-1153.

Cappelli, P., 2001. Making the Most of On-line Recruiting. Harvard Business Review, 79(3), pp.139-146.

Cheng, S. and Li, H., 2011. Spatial Varying Relationships of New Firm Formation in the United States. Regional Studies, 45(6), pp.773-789.

Cooper, A.C., Gimeno-Gascon, F.J. and Woo, C.Y., 1994. Initial Human and Financial Capital as Predictors of New Venture Performance. Journal of Business Venturing, 9(5), pp.371-395.

David, P.A. and Wright, G., 2003. General Purpose Technologies and Surges in Productivity. In: P.A. David and M. Thomas, eds. 2003. The Economic Future in Historical Perspective. New York, NY: Oxford University Press, pp.135-166.

Feldman, M.P. and Florida, R., 1994. The Geographic Sources of Innovation: Technological Infrastructure and Product Innovation in the United States. Annals of the Association of American Geographers, 84(2), pp.210-229.

Florida, R., 1995. Toward the Learning Region. Futures, 27(5), pp.527-536.

Fotheringham, A.S., Brunsdon, C. and Charlton, M.E., 2002. Geographically Weighted Regression: The Analysis of Spatially Varying Relationships. Chichester, UK: John Wiley \& Sons.

Fotheringham, A.S., Charlton, M.E. and Brunsdon, C., 1998. Geographically Weighted Regression: A Natural Evolution of the Expansion Method for Spatial Data Analysis. Environment and Planning A, 30(11), pp.1905-1927.

Friedman, J., Gerlowski, D.A. and Silberman, J., 1992. What Attracts Foreign Multinational Corporations? Evidence from Branch Plant Location in the United States. Journal of Regional Science, 32(4), 403-418.

Fritsch, M. and Falck, O., 2002. New Firm Formation by Industry over Space and Time: A Multilevel Analysis. Freiberg, Germany: Freiberg University of Mining and Technology. 
Fujita, M., Krugman, P. and Venables, A.J., 1999. The Spatial Economy: Cities, Regions, and International Trade. Cambridge, MA: MIT Press.

Glaeser, E.L., Kallal, H.D., Scheinkman, J.A. and Shleifer, A., 1992. Growth in Cities. Journal of Political Economy, 100(6), pp.1126-1152.

Gomez-Ibanez, J.A., 2003. Regulating Infrastructure: Monopoly, Contracts, and Discretion. Cambridge, MA: Harvard University Press.

Gompers, P. and Lerner, J., 2001. The Venture Capital Revolution. Journal of Economic Perspectives, 15(2), pp.145-168.

Grandon, E.K. and Pearson, J.M., 2004. Electronic Commerce Adoption: An Empirical Study of Small and Medium US Businesses. Information \& Management, 42(1), pp.197-216.

Griffith, D.A. and Krampf, R.F., 1998. An Examination of the Web-based Strategies of the Top 100 U.S. Retailers. Journal of Marketing Theory and Practice, 6(3), pp.12-23.

Guesnier, B., 1994. Regional Variations in New Firm Formation in France. Regional Studies, 28(4), pp.347-358.

Hamilton, B.H., 2000. Does Entrepreneurship Pay? An Empirical Analysis of the Returns to Self-employment. Journal of Political Economy, 108(3), pp.604-631.

Harris, R.G., 1998. The Internet as a GPT: Factor Market Implication. In: E. Helpman, ed. 1998. General Purpose Technologies and Economic Growth. Cambridge, MA: MIT Press, pp.145-166.

Hart, D.M. and Acs, Z.J., 2011. High-tech Immigrant Entrepreneurship in the United States. Economic Development Quarterly, 25(2), pp.116-129.

Haynes, K.E., 2006. Infrastructure: The Glue of Megacities. Hague: Kenniscentrum Grote Steden.

Holl, A., 2004. Transport Infrastructure, Agglomeration Economies, and Firm Birth: Empirical Evidence from Portugal. Journal of Regional Science, 44(4), pp.693-712.

Katz, M.L. and Shapiro, C., 1985. Network Externalities, Competition, and Compatibility. American Economic Review, 75(3), pp.424-440.

Krugman, P., 1998. What's New about the New Economic Geography?. Oxford Review of Economic Policy, 14(2), pp.7-17.

Lee, S.Y., Florida, R. and Acs, Z.J., 2004. Creativity and Entrepreneurship: A Regional Analysis of New Firm Formation. Regional Studies, 38(8), pp.879-891.

Li, H., Cheng, S. and Haynes, K.E., 2011. The Employment Effects of New Business Formation: A Regional Perspective. Economic Development Quarterly, 25(3), pp.282-292. 
Lipsey, R.G., Carlaw, K.I. and Bekar, C.T., 2005. Economic Transformation: General Purpose Technologies and Long Term Economic Growth. New York, NY: Oxford University Press.

Lomi, A., 1995. The Population Ecology of Organizational Founding: Location Dependence and Unobserved Heterogeneity. Administrative Science Quarterly, 40(1), pp.111-144.

Majumdar, S.K., Carare, O. and Chang, H., 2010. Broadband Adoption and Firm Productivity: Evaluating the Benefits of General Purpose Technologies. Industrial and Corporate Change, 19(3), pp.641-674.

Malecki, E.J., 1994. Entrepreneurship in Regional and Local Development. International Regional Science Review, 16(1-2), pp.119-153.

Markusen, A., 1996. Sticky Places in Slippery Space: A Typology of Industrial Districts. Economic Geography, 72(3), pp.293-313.

McQuaid, R.W., 2002. Entrepreneurship and ICT Industries: Support form Regional and Local Policies. Regional Studies, 36(8), pp.909-919.

Munnell, A.H., 1990. How Does Infrastructure Affect Regional Economic Performance?. New England Economic Review, September/October, pp.11-32.

Nijkamp, P., 1986. Infrastructure and Regional Development: A Multidimensional Policy Analysis. Empirical Economics, 11(1), pp.1-21.

Nijkamp, P., 2003. Entrepreneurship in a Modern Network Economy. Regional Studies, 37(4), pp.395-405.

Parajuli, J. and Haynes, K.E., 2012. Broadband Internet and New Firm Formation: A U.S. Perspective. Available at: $<$ https://papers.ssrn.com/sol3/papers.cfm?abstract_id=2144544> [Accessed Oct 2012].

Porter, M.E., 2000. Location, Competition, and Economic Development: Local Clusters in a Global Economy. Economic Development Quarterly, 14(1), pp.1534.

Prud'homme, R., 2005. Infrastructure and Development. In: F. Bourguignon and B. Pleskovic, eds. 2005. Lessons of Experience. Washington, DC: The World Bank and Oxford University Press, pp.153-180.

Reynolds, P.D., Miller, B. and Maki, W.R., 1995. Explaining Regional Variation in Business Births and Deaths: U.S. 1976-88. Small Business Economics, 7(5), pp.389-407.

Ruttan, V.W., 2008. General Purpose Technology, Revolutionary Technology, and Technological Maturity. St. Paul, MN: University of Minnesota.

Saxenian, A., 2002. Silicon Valley's New Immigrant High-growth Entrepreneurs. Economic Development Quarterly, 16(1), pp.20-31. 
Schumpeter, J.A., 1942. Capitalism, Socialism, and Democracy. New York, NY: Harper-Collins.

Sharma, A., 2002. Trends in Internet-based Business-to-Business Marketing. Industrial Marketing Management, 31(2), pp.77-84.

Spencer, R.W. and Yohe, W.P., 1970. The "Crowding Out" of Private Expenditures by Fiscal Policy Actions. Federal Reserve Bank of St. Louis Review, October, pp.12-24.

Storey, D.J., 1991. The Birth of New Firms: Does Unemployment Matter? A Review of the Evidence. Small Business Economics, 3(3), pp.167-178.

Stuart, T. and Sorenson, O., 2003. The Geography of Opportunity: Spatial Heterogeneity in Founding Rates and the Performance of Biotechnology Firms. Research Policy, 32(2), pp.229-253.

Sutaria, V. and Hicks, D.A., 2004. New Firm Formation: Dynamics and Determinants. Annals of Regional Science, 38(2), pp.241-262.

Uzzi, B., 1999. Embeddedness in the Making of Financial Capital: How Social Relations and Networks Benefit Firms Seeking Financing. American Sociological Review, 64(4), pp.481-505.

Van Praag, C.M. and Versloot, P.H., 2007. What is the Value of Entrepreneurship? A Review of Recent Research. Small Business Economics, 29(4), pp.351-382.

\section{ABOUT AUTHORS}

Jitendra Parajuli received his $\mathrm{PhD}$ (Public Policy) from George Mason University, US. His research interests include infrastructure, entrepreneurship, economic development, and public policy analysis. He can be reached at jparajuli@hotmail.com or +977-1-4811063.

Kingsley E. Haynes is Emeritus, Founding Dean, University Professor of Public Policy, Professor of Decision Sciences, Geography and Public Affairs, Hazel Endowed Chair and Eminent Scholar in the Schar School of Policy and Government at George Mason University in Arlington, Va. He holds his PhD in Geography and Environmental Engineering from the Johns Hopkins University. His is a Fellow of the National Academy of Public Administration and the Regional Science Association International and holds the Anderson Medal for Applied Research from the Association of American Geographers. His research is in the area of infrastructure policy and spatial economic analysis. 